\title{
Article \\ Somatic Embryogenesis and Plant Regeneration in Viola canescens Wall. Ex. Roxb.: An Endangered Himalayan Herb
}

\author{
Arun Kumar Khajuria ${ }^{1,2, *}$, Christophe Hano ${ }^{3,4}\left(\mathbb{D}\right.$ and Narendra Singh Bisht ${ }^{1}$ \\ 1 Plant Tissue Culture Laboratory, Department of Botany, Campus Pauri, HNB Garhwal University, \\ Pauri Garhwal 246001, Uttarakhand, India; nsbotany@gmail.com \\ 2 Department of Botany, Cluster University of Jammu, Jammu 184001, Jammu \& Kashmir, India \\ 3 Laboratoire de Biologie des Ligneux et des Grandes Cultures (LBLGC), INRAE USC1328, \\ Campus Eure et Loir, Université d'Orléans, F-28000 Chartres, France; hano@univ-orleans.fr \\ 4 Bioactifs et Cosmétiques, Centre National de la Recherche Scientifique (CNRS) GDR3711, \\ Université d'Orléans, CEDEX 2, F-45067 Orléans, France \\ * Correspondence: arun.khajuria20@gmail.com
}

check for

updates

Citation: Khajuria, A.K.; Hano, C.; Bisht, N.S. Somatic Embryogenesis and Plant Regeneration in Viola canescens Wall. Ex. Roxb.: An Endangered Himalayan Herb. Plants 2021, 10, 761. https://doi.org/ 10.3390/plants10040761

Received: 2 March 2021

Accepted: 12 April 2021

Published: 13 April 2021

Publisher's Note: MDPI stays neutral with regard to jurisdictional claims in published maps and institutional affiliations.

Copyright: (c) 2021 by the authors. Licensee MDPI, Basel, Switzerland. This article is an open access article distributed under the terms and conditions of the Creative Commons Attribution (CC BY) license (https:// creativecommons.org/licenses/by/ $4.0 /)$.
Abstract: Viola canescens Wall. ex. Roxb. is an important but threatened medicinal herb found at 1500$2400 \mathrm{~m}$ above mean sea level in the Himalayas. Overexploitation and habitat preference have put the plant under serious threat. Thus, the present study was undertaken to develop an efficient protocol for in vitro propagation via somatic embryogenesis. The results revealed that plant can be regenerated successfully through somatic embryogenesis using leaf derived calli. Regular subculturing of calli on Murashige and Skoog (MS) medium with 2,4-dichlorophenoxyacetic acid (2,4-D)/indole-3-butyric acid (IBA)/ kinetin ( $\mathrm{Kn}$ ) and varying combinations of 2,4-D+Kn induced somatic embryogenesis. The maximum average number of somatic embryos (SE) (19.15 \pm 2.66$)$ was induced on the medium with $0.15+0.05 \mathrm{mg} \mathrm{L}^{-1}$ of 2,4-D and $\mathrm{Kn}$, respectively, and this medium was used as a control. To enhance somatic embryo induction, the control MS medium was supplemented with L-glutamine (200-400 $\left.\mathrm{mg} \mathrm{L}^{-1}\right)$ and casein hydrolysate (1-4\%). The maximum average number of SE $(27.66 \pm 2.67)$ and average mature SE $(13.16 \pm 3.48)$ were recorded on the medium having $2 \%$ L-glutamine and 50 $\mathrm{mg} \mathrm{L}^{-1}$ casein hydrolysate. The induced SE were asynchronous, so, to foster their maturation, the culture medium (free from growth regulators) was supplemented with abscisic acid (ABA) and silver nitrate $\left(\mathrm{AgNO}_{3}\right)$. The maximum average number $(35.96 \pm 3.68)$ of mature SE was noticed on MS medium supplemented with $1.5 \mathrm{mg} \mathrm{L}^{-1}$ ABA. Mature embryos had two well-developed cotyledons and an elongated hypocotyl root axis. The development of SE into plantlets was significant for embryos matured on the medium with $\mathrm{AgNO}_{3}$ and $\mathrm{ABA}$, with $86.67 \%$ and $83.33 \%$ conversion on the medium with $0.20 \mathrm{mg} \mathrm{L}^{-1}$ 6-benzylaminopurine (BAP). The plantlets thus produced acclimatized in a growth chamber before being transferred to the field, which showed $89.89 \%$ survival. The plants were morphologically similar to the mother plant with successful flowering.

Keywords: callus; casein hydrolysate; silver nitrate; abscisic acid; cytokinin; survival

\section{Introduction}

Viola canescens Wall. ex, Roxb., (family Violaceae) is an important endangered Himalayan herb as reported by the International Union for Conservation of Nature and Natural Resources. In India, it is known by different names in different regions: Banfsha or Vanaksha in Jammu and Kashmir; Kauru, Vanafsha or Banfasha in Uttarakhand; and Ratmundi, Gugluphul and Banfsaha in Himachal Pradesh [1-3]. The plant is one of the preferred herbs and used in both codified (Ayurveda, Unani, Siddha, homeopathy) and non-codified (folk) medicinal systems. Traditionally, it is used to cure a number of common ailments (e.g., cold, cough and sore throat) and different life-threatening diseases such as jaundice, renal problems, cancer and respiratory tract problems, and is an immune 
booster and blood purifier [1,4-10]. The plant is also known to have different pharmacological activities such as antimalarial [11], antifungal [12] and antibacterial activities [13-16]. Solvent extracts of $V$. canescens also showed relevant antioxidant and hepatoprotective activities [17].

Somatic embryogenesis is one of the promising plant biotechnology tools to produce identical individuals and is a preferred choice for fast plant regeneration. The use of somatic embryogenesis cuts the cost of propagation because there is no requirement of cutting and inoculating the shoots into a rooting medium for further rhizogenesis. Besides this, for long-term maintenance of in vitro raised tissue (calli) or shoots, repeated subculturing is required. Somatic embryos (SE), on the other hand, have the ability to withstand long-term storage via cryopreservation. Development of a protocol for somatic embryogenesis may also allow the embryos to be stored as synthetic seeds and used when required.

The lack of organized cultivation strategies, high ethnomedicinal and pharmacological potential, habitat preference and illegal indiscriminate collection from the wild have resulted in depletion of this plant from its wild habitat at an alarming rate. In a continuation of our previous work on the plant [18-20], an attempt was made to regenerate plant via somatic embryogenesis, which may contribute to mass production of the plant by the tissue culture method to fill the demand and supply gap of this medicinally important plant. Successful regeneration of plants via somatic embryogenesis has been reported in a number of Himalayan herbs such as Podophyllum hexandrum [21], Picrorhiza kurroa [22], Swertia chirata [23], Angelica glauca [24], Gentiana kurroo [25] and Viola odorata [26]. Since no previous work has been reported, to the best of our knowledge, on somatic embryogenesis in Viola canescens, the present work was conducted to develop an efficient regeneration protocol for Viola canescens through somatic embryogenesis. During this study, various factors were optimized to provide a protocol that may support its commercial production.

\section{Material and Methods}

\subsection{Plant Material and Surface Sterilization}

The leaves of Viola canescens were collected from its natural habitat located at latitude $30^{\circ} 8^{\prime} 59^{\prime \prime} \mathrm{N}$ and longitude $78^{\circ} 49^{\prime} 4^{\prime \prime} \mathrm{E}$ in the Nag Dev Hills of the Garhwal (Pauri) Himalayas. Collected plants from a single genotype were initially treated with lukewarm water with 2-3 drops of liquid soap with constant stirring for $10 \mathrm{~min}$ and repeating the same for 5 more mins by adding 2 drops of Tween-20. Finally, the flask was placed under running tap water for $15 \mathrm{~min}$. Surface sterilization of the explants was carried out in a laminar air chamber; a $0.1 \%$ mercury chloride solution $w / v$ was used for $90 \mathrm{~s}$ and then washed repeatedly with double-distilled autoclaved water to remove all traces of mercury chloride.

\subsection{Culture Medium and Culture Conditions}

Surface sterilized leaf explants were then blotted dry and prepared by trimming with the help of a scalpel and inoculated in the callus inducing medium [18,19]. Murashige and Skoog (MS) [19] medium supplemented with 3\% $(w / v)$ sucrose (Hi Media, India), $0.8 \%(w / v)$ agar (Hi Media, India), $1.5 \mathrm{mg} \mathrm{L}^{-1}$ 2,4-dichlorophenoxy acetic acid (2,4-D) and $1.5 \mathrm{mg} \mathrm{L}^{-1}$ Kinetin $(\mathrm{Kn})$ was used as a culture medium. The $\mathrm{pH}$ of the medium was adjusted to $5.8 \pm 0.2$ prior to autoclaving. All cultures were maintained at $25 \pm 2{ }^{\circ} \mathrm{C}$ temperature with a $16 / 8 \mathrm{hr}$ photoperiod at 1000 lux light, and the humidity of the culture room was maintained at $60-70 \%$.

\subsection{Standardization of Somatic Embryogenesis}

\subsubsection{Induction of SE}

The embryogenic callus mass from leaf calli $(300 \mathrm{mg})$ for somatic embryogenesis was transferred to MS medium with 2,4-D (0.10-0.25 mg L $\left.{ }^{-1}\right)$, indole-3-butyric acid (IAB) $\left(0.10-0.25 \mathrm{mg} \mathrm{L}^{-1}\right), \mathrm{Kn}\left(0.10-0.50 \mathrm{mg} \mathrm{L}^{-1}\right)$ and $2,4-\mathrm{D}+\mathrm{Kn}(0.10+0.05 ; 0.15+0.05 ; 0.20+0.05$ and $0.25+0.05 \mathrm{mg} \mathrm{L}^{-1}$ ) for 6 weeks. The induction frequency was calculated by using the 
equation "number of cultures showing SE embryos divided by total culture inoculated". Each experiment was done in triplicate.

\subsubsection{Abscisic Acid and Silver Nitrate}

Twelve-week-old callus mass ( $300 \mathrm{mg} ; 8$ weeks on the culture medium +4 weeks on the embryo induction medium) was used to study the effect of abscisic acid (ABA) (0.5-2.0 $\left.\mathrm{mg} \mathrm{L}^{-1}\right)$, silver nitrate $\left(\mathrm{AgNO}_{3}\right)\left(1.0-3.0 \mathrm{mg} \mathrm{L}^{-1}\right)$ and growth regulator-free MS medium for SE maturation for 30 days. Both solutions were prepared fresh and the ABA solution was used after filter sterilization. Each experiment was done in triplicate.

\subsubsection{Germination of SE}

Mature (cotyledon stage) SE from both treatments $\mathrm{ABA}$ and $\mathrm{AgNO}_{3}$ were transferred to MS medium supplemented with different concentrations of 6-benzylaminopurine (BAP) (0.10-0.50 $\left.\mathrm{mg} \mathrm{L}^{-1}\right)$ and $\mathrm{Kn}\left(0.10-0.50 \mathrm{mg} \mathrm{L}^{-1}\right)$. MS medium without growth regulators was used as a control. In total, 48 SE were inoculated in the control medium, and 16 and 20 mature SE with Kn and BAP, respectively, which was repeated thrice. Germination percentage was determined by the number of mature embryos germinated divided by the number of mature SE taken from their respective treatments. Each experiment was done in triplicate.

\subsubsection{Use of L-Glutamine and Casein Hydrolysate for Induction and Germination of SE}

To study the effect of L-glutamine (50-200 $\left.\mathrm{mg} \mathrm{L}^{-1}\right)$, casein hydrolysate $(1-4 \% w / v)$ and casein + L-glutamine $\left(1 \%+50 \mathrm{mg} \mathrm{L}^{-1} ; 2 \%+50 \mathrm{mg} \mathrm{L}^{-1}\right.$ and $\left.2 \%+100 \mathrm{mg} \mathrm{L}^{-1}\right)$ for the further enhancement of somatic embryogenesis and regeneration of SE, equal amounts (300 mg) of 8-week leaf-derived callus was transferred to modified MS medium (MS medium with 2,4D $0.15 \mathrm{mg} \mathrm{L}^{-1}+\mathrm{Kn} 0.05 \mathrm{mg} \mathrm{L}^{-1}$ ). The mature SE (20 per culture tube) were then inoculated on the culture medium (induction medium) to observe the germination potential of the same medium (2,4-D and Kn was removed from cultures during embryo germination).

\subsection{Acclimatization}

In vitro raised complete elite plantlets were removed from the cultures and washed gently with distilled water to remove agar without damaging the delicate root system. Plantlets then transferred to (i) control garden soil (ii) forest soil + organic compost + sand $(1: 1: 1 \mathrm{v} / \mathrm{v})$ and (iii) rhizospheric forest soil + organic compost $(2: 1 \mathrm{v} / \mathrm{v})$. The plantlets were initially placed in an environmental chamber under controlled conditions (1500 lux light for 3 days, followed by 2000 lux for the next 3 days and finally at 2500 lux light for the remaining days) under a $16 \mathrm{~h}$ photoperiod for 2 weeks and then diffuse light, and were irrigated with a dilute nutrient solution (every third day). The temperature of the environment chamber was maintained at $21^{\circ} \mathrm{C} \pm 1{ }^{\circ} \mathrm{C}$. A dome made from a polythene bag with small holes ( $0.5 \mathrm{~mm}$ diameter) or sometimes glass beakers, as per requirements, was also used. The survival percentage was computed for the successfully established plants. The hardened plants were then transferred to earthen pots under environmental conditions. Plants were irrigated frequently and their growth and variation were monitored periodically.

\subsection{Data Analysis}

All the cultures were examined periodically and the data were pooled from 3 independent experiments. The effect of different treatments was analyzed using one-way analysis of variance (ANOVA) and the difference between their means was compared using Duncan's Multiple Range Test (DMRT), a post hoc test, at $p<0.05$. All the analyses were carried out using SPSS 16.0. 


\section{Results and Discussion}

\subsection{Somatic Embryo Induction}

Callus was initiated from the leaf of $V$. canescens [18]. The generated callus was sub-cultured on a selected concentration of 2,4-D and $\mathrm{Kn}\left(1.5+1.5 \mathrm{mg} \mathrm{L}^{-1}\right)$ for 8 weeks. These 8-week-old embryogenic calli were then inoculated on MS medium for somatic embryogenesis responses, and 2,4-D, IBA and Kn were used to induce somatic embryogenesis. Different concentrations of 2,4-D and IBA $\left(0.10-0.25 \mathrm{mg} \mathrm{L}^{-1}\right)$ were used to induce somatic embryogenesis. The results for both growth regulators remained significant $(p \leq 0.5)$, with 2,4-D proving superior over the IBA for both somatic embryo induction as well as the number of SE per clump. The maximum frequency $(77.77 \%)$ and number of SE $(17.55 \pm 2.90)$ formed on the medium supplemented with $0.15 \mathrm{mg} \mathrm{L}^{-1} 2,4-\mathrm{D}$. The superiority of 2,4-D for somatic embryogenesis has been reported for Foeniculum vulgae [27], Bunium persicum [28], Chlorophytum borivilianum [29] and Sapindus mukorossi [30]. Besides this, the results showed profuse rooting in those callus clumps which were inoculated on MS medium supplemented with $0.10 \mathrm{mg} \mathrm{L}^{-1}$ 2,4-D, while beyond $0.15 \mathrm{mg} \mathrm{L}^{-1}$, the potential of 2,4-D and IBA for SE ceases. Different concentrations of Kn (0.10-0.50 $\left.\mathrm{mg} \mathrm{L}^{-1}\right)$ were also evaluated to induce somatic embryos. The maximum frequency $(55.55 \%)$ and average number $(13.11 \pm 2.29)$ were reported when the culture medium was supplemented with $0.20 \mathrm{mg} \mathrm{L}^{-1}$ and $0.25 \mathrm{mg} \mathrm{L}^{-1}$ concentrations, respectively. Further, beyond $0.25 \mathrm{mg} \mathrm{L}^{-1}$ concentration, shoot formation was reported from the inoculated callus. Cytokinin alone can produce SE, as reported in Sapindus mukorossi [30], Corydalis yanhusuo [31] and Oncidium [32]. However, in most cases, cytokinin is supplemented in MS medium with auxin for better results. The role of 2,4-D in SE induction has been well documented in various plant species [33,34], and the molecular mechanism, acting in particular through the modulation of endogenous hormonal levels, has been recently reviewed [35]. The present study is also in agreement with the early finding: the maximum induction frequency $(88.88 \%)$ and average number of SE $(19.15 \pm 2.66)$ were reported when the 2,4-D + Kn $(0.15+0.05)$ combination was tried (Table 1). 
Table 1. Effect of PGRs on somatic embryogenesis in leaf-derived 8-week calli of $V$. canescens after 6 weeks of culture.

\begin{tabular}{|c|c|c|c|c|c|c|}
\hline \multicolumn{4}{|c|}{ Concentration (mg L $\left.{ }^{-1}\right)$} & \multirow{2}{*}{ Response } & \multirow{2}{*}{$\begin{array}{l}\text { Frequency of } \\
\text { Embryogenesis }\end{array}$} & \multirow{2}{*}{$\begin{array}{c}\text { Number of SE } \\
\text { Derived from } 300 \\
\text { mg Callus }\end{array}$} \\
\hline 2,4-D & IBA & Kn & 2,4-D + Kn & & & \\
\hline 0.10 & & & & RT & n.d. & n.d. \\
\hline 0.15 & & & & SE & 77.77 & $17.55 \pm 2.90^{b}$ \\
\hline 0.20 & & & & $\mathrm{SE}$ & 59.26 & $15.14 \pm 2.89^{c}$ \\
\hline \multirow[t]{14}{*}{0.25} & & & & CA & n.d. & n.d. \\
\hline & 0.10 & & & $\mathrm{CA}$ & n.d. & n.d. \\
\hline & 0.15 & & & $\mathrm{SE}$ & 29.62 & $8.03 \pm 2.06^{\mathrm{f}}$ \\
\hline & 0.20 & & & $\mathrm{SE}$ & 37.03 & $10.66 \pm 2.46^{\mathrm{e}}$ \\
\hline & 0.25 & & & CA & n.d. & n.d. \\
\hline & & 0.10 & & CA & n.d. & n.d. \\
\hline & & 0.15 & & $\mathrm{CA}$ & n.d. & n.d. \\
\hline & & 0.20 & & $\mathrm{SE}$ & 55.55 & $10.25 \pm 2.26^{\mathrm{e}}$ \\
\hline & & 0.25 & & $\mathrm{SE}$ & 48.14 & $13.11 \pm 2.29 \mathrm{~d}$ \\
\hline & & 0.50 & & SH & n.d. & n.d. \\
\hline & & & $0.10+0.05$ & CA & n.d. & n.d. \\
\hline & & & $0.15+0.05$ & $\mathrm{SE}$ & 88.88 & $19.15 \pm 2.66^{\mathrm{a}}$ \\
\hline & & & $0.20+0.05$ & $\mathrm{SE}$ & 70.37 & $16.81 \pm 3.02^{b}$ \\
\hline & & & $0.25+0.05$ & SE & 62.96 & $15.22 \pm 3.01^{\mathrm{c}}$ \\
\hline
\end{tabular}

$\mathrm{CA}=$ Callus; $\mathrm{SH}=$ Shoots; $\mathrm{SE}=$ Somatic embryos; RT = Profuse rooting; PRGs: plant growth regulators; n.d., not detected. Data were polled from three independent experiments $(n=27)$, where the values represent means \pm SD. Means followed by the same letter in the column are non-significantly different by Duncan's Multiple Range Test (DMRT) $(p=0.05)$.

After selecting the optimum concentration of 2,4-D and Kn for somatic embryo induction, the selected concentration was tried with L-glutamine, an amino acid, in a concentration range of $\left(50-200 \mathrm{mg} \mathrm{L}^{-1}\right)$ and casein hydrolysate $(1-4 \% \mathrm{w} / v)$ and their combinations for further enhancement of somatic embryogenesis. Addition of both gave significant results as compared with the control (Table 2).

Table 2. Effect of L-glutamine and casein hydrolysate on somatic embryogenesis in 8-week calli of $V$. canescens grown on MS* medium.

\begin{tabular}{|c|c|c|c|c|}
\hline Treatment & Concentration & $\begin{array}{l}\text { Number of SE } \\
\text { per Callus } \\
\text { Clump }\end{array}$ & Mature SE & $\begin{array}{c}\text { Germination } \\
\text { Percentage }(\%) \\
\text { per } 20 \text { Mature } \\
\text { SE }\end{array}$ \\
\hline \multirow{4}{*}{$\begin{array}{l}\text { Control } \\
\text { L-Glutamine } \\
\left(\mathrm{mg} \mathrm{L}^{-1}\right)\end{array}$} & & $19.33 \pm 2.9$ & n.d. & n.d. \\
\hline & 50 & $18.94 \pm 1.95^{\mathrm{e}}$ & n.d. & n.d. \\
\hline & 100 & $23.33 \pm 2.76^{\mathrm{cd}}$ & $9.05 \pm 3.13^{c}$ & 20 \\
\hline & 200 & $19.05 \pm 2.66^{\mathrm{e}}$ & $5.11 \pm 3.54^{\mathrm{e}}$ & 15 \\
\hline \multirow[t]{4}{*}{ Casein $(\% w / v)$} & 1 & $21.66 \pm 2.80^{\mathrm{d}}$ & n.d. & n.d. \\
\hline & 2 & $25.88 \pm 2.56^{b}$ & $12.16 \pm 3.39 \mathrm{ab}$ & 55 \\
\hline & 3 & $18.89 \pm 2.05^{\mathrm{e}}$ & $7.33 \pm 3.69^{d}$ & 45 \\
\hline & 4 & $13.05 \pm 3.53^{f}$ & $2.38 \pm 1.97^{f}$ & n.d. \\
\hline \multirow[t]{3}{*}{$\begin{array}{c}\text { Casein+ } \\
\text { L-Glutamine }\end{array}$} & $1 \%+50 \mathrm{mg} \mathrm{L}^{-1}$ & $21.61 \pm 2.93^{d}$ & $10.61 \pm 2.68^{\mathrm{bc}}$ & 60 \\
\hline & $2 \%+50 \mathrm{mg} \mathrm{L}^{-1}$ & $27.66 \pm 2.67^{\mathrm{a}}$ & $13.16 \pm 3.48^{a}$ & 55 \\
\hline & $\begin{array}{c}2 \%+100 \mathrm{mg} \\
\mathrm{L}^{-1}\end{array}$ & $24.16 \pm 2.57^{b c}$ & $10.83 \pm 1.82^{\mathrm{bc}}$ & 35 \\
\hline
\end{tabular}

n.d.: not detected. Data are from three independent experiments $(n=18)$, where the values represent means $\pm \mathrm{SD}$. Means followed by the same letter in the column are non-significantly different by DMRT $(p=0.05)$. Data for germination percentage per $20 \mathrm{SE}$ without growth regulators were recorded after 30 days. MS* $=$ MS medium with $0.15+0.05 \mathrm{mg} \mathrm{L}^{-1}$ 2,4-dichlorophenoxyacetic acid (2,4-D) and kinetin $(\mathrm{Kn})$.

During study, it was further noticed that development of SE beyond the globular stage was inhibited in cultures with auxins (IBA and 2,4-D) and cytokinin (Kn). The inhibitory effect of auxin on maturation was reported by number of workers [36-40]. However, when L-glutamine, casein hydrolysate and their combinations were used (Table 2), the culture medium showed maturation of SE, but the SE were asynchronous and different stages 
of embryogenesis could be seen in the same culture, coupled with a slow maturation rate. The maximum average number of SE $(27.66 \pm 2.67)$ and maximum mature embryos $(13.16 \pm 3.48)$ were reported in modified MS medium supplemented with a combination of casein hydrolysate and L-glutamine $\left(2 \%+50 \mathrm{mg} \mathrm{L}^{-1}\right)$, respectively. The SE were then regenerated on the same medium (but without 2,4-D and $\mathrm{Kn}$ ) in which they matured. The maximum average germination percentage was reported in MS medium supplemented with $\left(2 \%+50 \mathrm{mg} \mathrm{L}^{-1}\right)$ casein hydrolysate and L-glutamine. The addition of L-glutamine and casein hydrolysate, as sources of amino acid, to enhance somatic embryogenesis has been reported [33-44].

\subsection{Maturation of SE}

To enhance this rate of maturation, early SE were transferred to a medium without growth regulators for their maturation and supplemented with $\mathrm{AgNO}_{3}\left(1.0-3.0 \mathrm{mg} \mathrm{L}^{-1}\right)$ and ABA $\left(0.5-2.0 \mathrm{mg} \mathrm{L}^{-1}\right)$. The use of silver nitrate improved the rate of SE maturation, with the maximum average number of SE $(22.81 \pm 3.85)$ observed when $1.0 \mathrm{mg} \mathrm{L}^{-1}$ was supplemented in the medium. However, ABA proved more suitable for SE maturation, with an average of $35.96 \pm 3.68$ mature SE observed in the MS medium supplemented with $1.5 \mathrm{mg} \mathrm{L}^{-1}$ ABA. Addition of $\mathrm{AgNO}_{3}$ and $\mathrm{ABA}$ improved maturation has been reported in carrot SE [45], Phoenix dactylifera [46], Psidium guajava [47] and Chlorophytum borivilianum [48], in agreement with the present work. The action of ABA on maturation has been well-described for both embryos and SE [35], acting through complete transcriptional reprogramming involving master regulators such as ABI3 (ABA Insensitive 3) [49-51]. Ethylene may antagonize $\mathrm{ABA}$ action during maturation [45,52]. The use of $\mathrm{AgNO}_{3}$, an inhibitor of ethylene biosynthesis, may help in obtaining effective maturation [45]. The action of $\mathrm{AgNO}_{3}$ has been reported to act through its inhibition of arginine decarboxylase in ethylene biosynthesis [45].

\subsection{SE Germination}

The mature SEs derived from three different treatments (i.e., SEs matured on the control (MS medium without growth regulators), the medium with $\mathrm{ABA}$ and the medium with $\mathrm{AgNO}_{3}$ ) (Table 3). These embryos were regenerated on MS medium, and MS medium supplemented with BAP $\left(0.10-0.50 \mathrm{mg} \mathrm{L}^{-1}\right)$ and $\mathrm{Kn}\left(0.10-0.50 \mathrm{mg} \mathrm{L}^{-1}\right)$. An experiment was conducted to analyze the interaction of $\mathrm{ABA}$ and $\mathrm{AgNO}_{3}$ with $\mathrm{SE}$ and their rate of conversion into plantlets. MS medium with (Kn and BAP) or without cytokinin was used for the conversion of mature SEs into plantlets (plantlets with a minimum of one shoot and one root). Mature SE were transferred to MS to produce plantlets because the mature SE could accumulate all the proteins and enzymes necessary to germinate into plantlets.

Table 3. Effects of abscisic acid (ABA) and silver nitrate on the maturation of somatic embryos in $V$. canescens after 30 days on MS medium without PGRs.

\begin{tabular}{ccc}
\hline Treatments & Concentration $\left(\mathbf{m g ~ L}^{-1)}\right.$ & $\begin{array}{c}\text { Number of Mature SE per } \\
\text { Callus }\end{array}$ \\
\hline Control & & $21.25 \pm 2.48^{\text {ef }}$ \\
ABA & 0.5 & $24.81 \pm 2.94^{\mathrm{d}}$ \\
& 1.0 & $29.59 \pm 3.52^{\mathrm{b}}$ \\
Silver nitrate & 1.5 & $35.96 \pm 3.68^{\mathrm{a}}$ \\
& 2.0 & $27.70 \pm 2.85^{\mathrm{c}}$ \\
& 1.0 & $22.81 \pm 3.85^{\mathrm{e}}$ \\
& 2.0 & $19.59 \pm 2.73^{\mathrm{f}}$ \\
& 3.0 & $20.88 \pm 3.27^{\mathrm{f}}$ \\
\hline
\end{tabular}

PRGs: plant growth regulators; Data were obtained from three independent experiments $(n=27)$, where values represent means $\pm \mathrm{SD}$. Means followed by the same letter in the column are non-significantly different by DMRT $(p=0.05)$. 
There was $47.91 \%$ and $52.08 \%$ conversion of plantlets from mature embryos with $\mathrm{ABA}$ and $\mathrm{AgNO}_{3}$, respectively, in the MS medium without growth regulators, which is in agreement with the results of a number of workers [22,53]. The plantlet conversion from embryos matured on media with two different agents $\left(\mathrm{ABA}\right.$ and $\left.\mathrm{AgNO}_{3}\right)$ was significant when BAP and Kn were tested. The maximum average conversion frequency $(86.66 \%)$ was recorded when the MS medium was supplemented with $0.10 \mathrm{mg} \mathrm{L}^{-1}$ BAP for the SE matured on the medium with $\mathrm{AgNO}_{3}$ as an agent of maturation; $83.33 \%$ plantlet formation was reported for embryos matured on the medium with ABA. The two cytokinins, BAP $\left(0.10-0.50 \mathrm{mg} \mathrm{L}^{-1}\right)$ and $\mathrm{Kn}\left(0.10-0.50 \mathrm{mg} \mathrm{L}^{-1}\right)$, strongly promoted plantlet formation when compared with the control (Table 4, Figure 1).

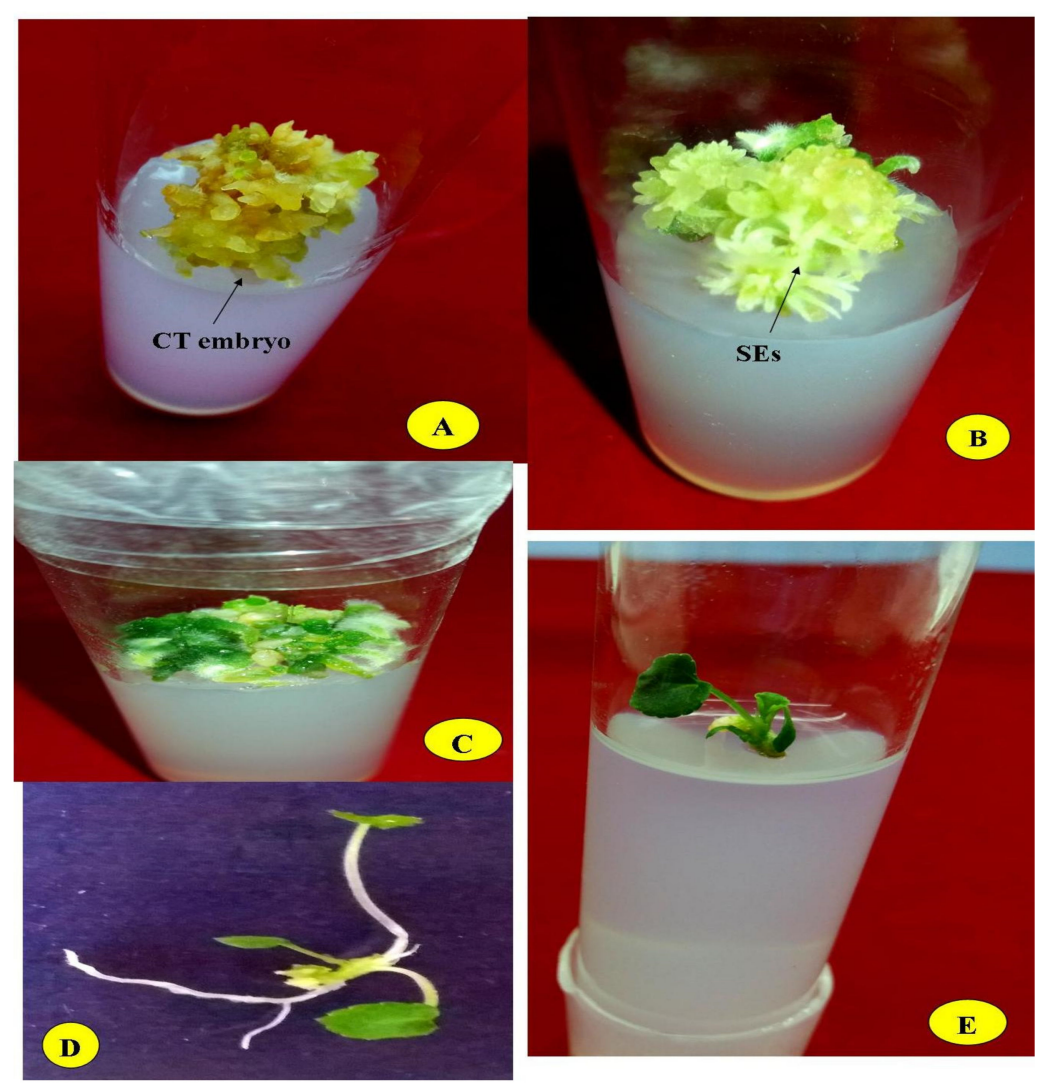

Figure 1. Plant regeneration through somatic embryogenesis in $V$. canescens from leaf explants. (A) Asynchronous SE on Murashige and Skoog (MS) medium $0.15+0.05 \mathrm{mg} \mathrm{L}^{-1}(2,4-\mathrm{D}+\mathrm{Kn})$. (B) SE on MS medium supplemented with casein hydrolysate + L-glutamine $\left(2 \%+50 \mathrm{mg} \mathrm{L}^{-1}\right)$. (C) Mature SE. (D,E). Plantlets regenerated from mature SE. 
Table 4. Effect of different PGRs on conversion of somatic embryos (SE) into plantlets in V. canescens after 30 days.

\begin{tabular}{|c|c|c|c|c|c|c|}
\hline $\begin{array}{c}\text { BAP } \\
\left(\mathrm{mg} \mathrm{L}^{-1}\right)\end{array}$ & $\begin{array}{c}\mathrm{Kn} \\
\left(\mathrm{mg} \mathrm{L}^{-1}\right)\end{array}$ & $\begin{array}{l}\text { Number of SE } \\
\text { Cultured }\end{array}$ & Response of SE & $\begin{array}{c}\text { Frequency of } \\
\text { Plantlet Formation } \\
\text { in SE Matured on } \\
\text { the Medium with } \\
\text { ABA }\end{array}$ & Response of SE & $\begin{array}{c}\text { Frequency of } \\
\text { Plantlet Formation } \\
\text { in SE Matured on } \\
\text { the Medium with } \\
\mathrm{AgNO}_{3}\end{array}$ \\
\hline Control & & 48 & PL & 47.91 & PL & 52.08 \\
\hline 0.10 & & 60 & PL & 83.33 & PL & 86.67 \\
\hline 0.20 & & 60 & PL & 73.33 & PL & 81.67 \\
\hline 0.35 & & 60 & MR & 28.33 & SH & n.d. \\
\hline \multirow[t]{5}{*}{0.50} & & 60 & SH & n.d. & SH & n.d. \\
\hline & 0.10 & 48 & PL & 77.08 & PL & 81.25 \\
\hline & 0.20 & 48 & MR & 43.75 & PL & 75.00 \\
\hline & 0.35 & 48 & $\mathrm{SH}$ & n.d. & MR & 64.58 \\
\hline & 0.50 & 48 & SH & n.d. & $\mathrm{SH}$ & n.d. \\
\hline
\end{tabular}

PRGs: plant growth regulators; .d. = not detected; $\mathrm{PL}=$ plantlets; $\mathrm{SH}=$ shoots $\mathrm{MR}=$ mixed results (plantlets and shoots).

SE conversion declined in higher concentrations of both cytokinins, as previously reported $[28,29,54-56]$. Higher concentrations of both plant growth regulators (PGRs) supported organogenesis (shoot formation only) from the mature embryos and resulted in a decline in the conversion frequency in the present study.

\subsection{Acclimatization}

The success of a plant tissue culture protocol depends upon the rate of plantlets survived outside the laboratory, because of a high mortality rate during the lab to field transfer [57-59]. The plantlets produced experimentally during the present study were acclimatized by keeping them in a growth chamber for 2 weeks. The plantlets were planted initially in thermocol cups and paper cups filled with sterilized soil (rhizospheric soil + organic compost at a 2:1 $w / v$ ratio and forest soil + organic compost + sand at a 1:1:1 $v / v$ ratio). The cups were then placed in a growth chamber under controlled conditions and watered regularly with $1 / 10$ strength MS medium every third day before transferring the plants to earthen pots. Survival percentage was computed by counting the plants producing new leaves, and the results were significantly affected by the soil composition and acclimatization conditions (Table 5, Figure 2). The plantlets maintained in the control showed zero survival percentage, and the maximum percentage $88.89 \%$ was reported for the plantlets planted in rhizospheric soil.

Table 5. Acclimatization of in vitro-raised plantlets of $V$. canescens.

\begin{tabular}{|c|c|c|c|c|c|}
\hline $\begin{array}{l}\text { Number of } \\
\text { Plantlets }\end{array}$ & $\begin{array}{l}\text { Plantlet } \\
\text { Type }\end{array}$ & $\begin{array}{c}\text { Duration in } \\
\text { Growth } \\
\text { Chamber } \\
\text { (Weeks) }\end{array}$ & $\begin{array}{l}\text { Irrigated } \\
\text { with }\end{array}$ & $\begin{array}{l}\text { Grown in } \\
\text { Shade (Time } \\
\text { Period in } \\
\text { Weeks) }\end{array}$ & Survival \% \\
\hline 30 & SE & 0 & Water & 0 & 00.00 \\
\hline \multicolumn{6}{|c|}{ Rhizospheric forest soil + organic compost $(2: 1 v / v)$} \\
\hline 45 & SE & 2 & $\begin{array}{c}1 / 10 \mathrm{MS} \\
\text { medium + } \\
\text { water }\end{array}$ & 2 & 88.89 \\
\hline \multicolumn{6}{|c|}{ Forest soil+ organic compost + sand (1:1:1 v/v) } \\
\hline 45 & SE & 2 & $\begin{array}{l}1 / 10 \mathrm{MS} \\
\text { medium + } \\
\text { water }\end{array}$ & 2 & 73.33 \\
\hline
\end{tabular}




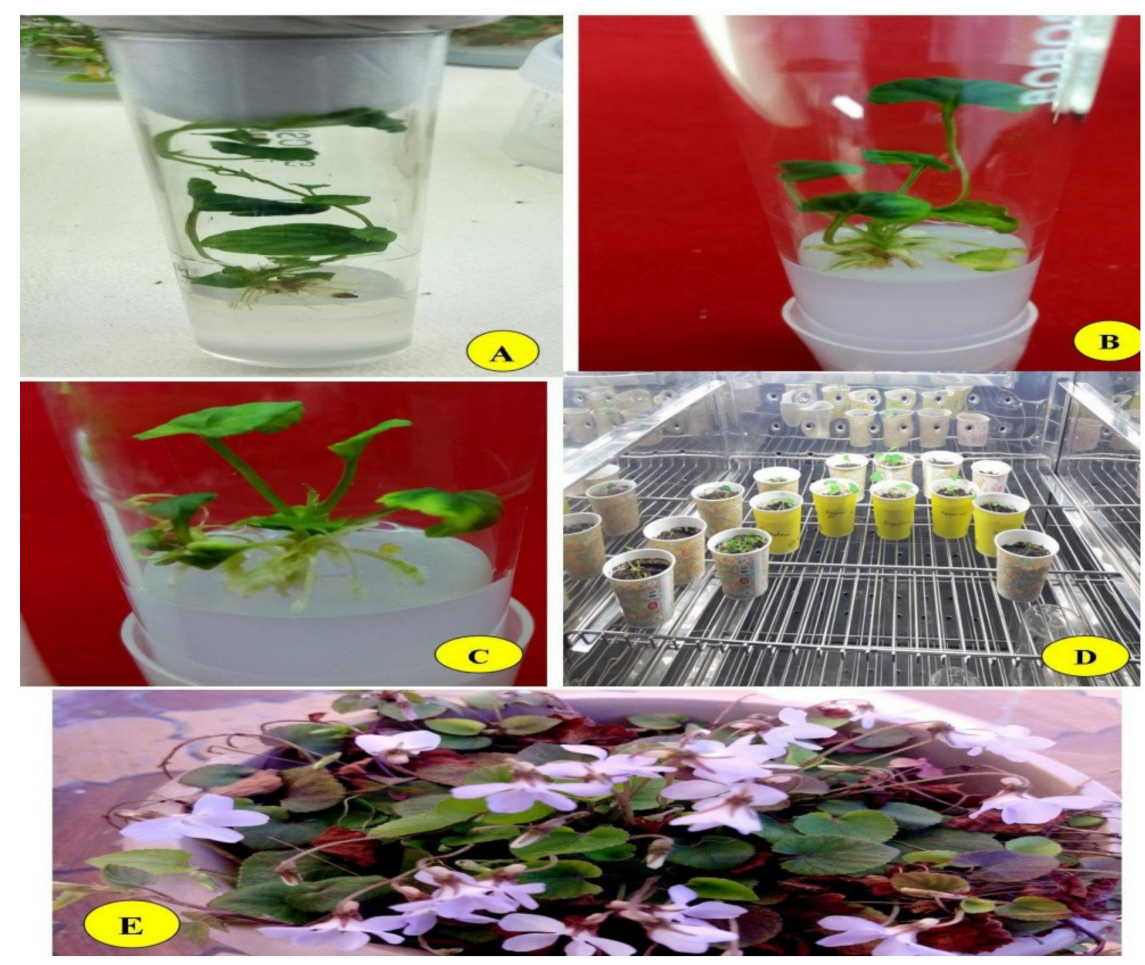

Figure 2. Regenerated $V$. canescens plants on MS medium (A-C). Plantlet acclimatization in the growth chamber (D). Representative 1-year-old established plantlet at the flowering stage (E).

\section{Conclusions}

The present paper is the first report on somatic embryogenesis in $V$. canescens to the best of our knowledge, as there are no previous reports of such studies so far for this medicinal plant. In the present study, the initiation of SE from leaf-derived calli in $V$. canescens was successfully achieved. The study focused on establishing the protocol for the production of high-quality SE; subsequently, the healthy plantlets had a high survival percentage. Maturation and germination of SE was worked out in detail. The addition of Lglutamine and casein hydrolysate to the MS medium promoted somatic embryo induction and maturation, while silver nitrate may be used for maturation of SE. The mature embryo showed a good rate of conversion when supplemented with BAP. Thus, the present protocol may be used to produce plants at a larger scale to meet the gap of demand and supply, and, at the same time, for its conservation. Finally, the application of the same protocol could be evaluated for in situ and ex situ conservation strategies in other endangered species of the genus Viola [60-62] at a global level.

Author Contributions: Conceptualization, investigation, data curation, writing-original draft preparation, writing — review and editing, A.K.K. Data curation and interpretation, writing-review and editing, C.H. Supervision, resources, N.S.B. All authors have read and agreed to the published version of the manuscript.

Funding: This research received no external funding.

Data Availability Statement: All the data are included in the present study.

Acknowledgments: The first author is greatly thankful to Prof. AK Dobriyal (HOD Zoology) for providing lab facilities in their department when required. Acknowledgment is due to Dr. Koshal Kumar and Mr. Sudesh Kumar (Zoology department) for their help during work in their department. The authors are also thankful to Mr. Vinay Kumar and Mr. V.S. Gussain for providing unconditional help during the acclimatization work. C.H. acknowledges Le Studium Institute for Advanced Studies for their support (Consortium Cosmenovic) and Cosmetosciences, a global training center located in the heart of the Cosmetic Valley, led by the University of Orléans and supported by the Région Centre-Val de Loire. 
Conflicts of Interest: The authors declare no conflict of interest.

\section{References}

1. Rana, C.S.; Sharma, A.; Kumar, N.; Dangwal, L.R.; Tiwari, J.K. Ethnopharmacology of some important medicinal plants of Nanda Devi National Park (NDNP) Uttarakhand. India. Nat. Sci. 2010, 8, 9-14.

2. Masood, M.; Arshad, M.; Asif, S.; Chaudhari, S.K. Viola canescens: Herbal wealth to be conserved. J. Bot. 2014. [CrossRef]

3. Mann, N.; Khajuria, A.K.; Uniyal, P.L.; Lakhanpaul, S. Viola canescens: A potent medicinal herb of Himalaya. Botanica 2016, 66, $58-62$.

4. Hamayun, M.; Khan, S.A.; Sohn, E.Y.; Lee, I.J. Folk medicinal knowledge and conservation status of some economically valued medicinal plants of District Swat, Pakistan. Lyonia 2006, 11, 101-113.

5. Abbasi, A.M.; Khan, M.A.; Ahmed, M.; Zafar, M. Herbal medicines used to cure various ailments by the inhabitants of Abbottabad district, North West Frontier Province, Pakistan. Indian J. Tradit. Knowl. 2010, 9, 175-183.

6. Hussain, I.; Bano, A.; Ullah, F. Traditional drug therapies from various medicinal plants of central karakoram national park, Gilgit-Baltistan Pakistan. Pak. J. Bot. 2011, 43, 79-84.

7. Kumar, S.; Chand, G.; Sankhyan, P.; Chaudhari, M.; Kumar, V.; Gupta, V.; Keshari, B.B.; Sundaresan, S. Herbal folk remedies for curing various ailments in Lug Valley of district Kullu, Himachal Pradesh (NW Himalaya). Int. J. Ayurvedic Herb. Med. 2013, 3, 1308-1314.

8. Rana, P.K.; Kumar, P.; Singhal, V.K.; Rana, C. Uses of local plant biodiversity among the tribal community of Pangi Valley of district Chamba in cold desert Himalaya, India. Sci. World J. 2014. [CrossRef]

9. Razzaq, A.; Hadi, F.; Rashid, A.; Ibrar, M.; Ali, U. Exploration of medicinal plants and their conservation status at higher altitude of district Shangla, Khyber Pakhtunkhwa, Pakistan. Am. Eurasian J. Agric. Environ. Sci. 2015, 15, 328-331.

10. Ahmad, K.S.; Qureshi, R.; Hameed, M.; Ahmad, F.; Nawaz, T. Conservation assessment and medicinal importance of some plants resources from Sharda, Neelum valley, Azad Jammu and Kashmir, Pakistan. Int. J. Agric. Biol. 2012, 14, 997-1000.

11. Verma, G.; Dua, V.K.; Agarwal, D.D.; Atul, P.K. Antimalarial activity of Holarrhena antidysenterica and Viola canescens, plants traditionally used against malaria in the Garhwal region of north-west Himalaya. Malar J. 2011, 10, 20. [CrossRef]

12. Rawal, P.; Adhikari, R.; Tiwari, A. Antifungal activity of Viola canescens against Fusarium oxysporum f. sp. lycopersici. Int. J. Curr. Microbiol. Appl. Sci. 2015, 4, 1025-1032.

13. Prasad, D. Antimicrobial activities of whole plant of Voila canescens and Bauhinia variegate. Biosci. Biotechnol. Res. Asia 2014, 11, 357-358. [CrossRef]

14. Khajuria, A.K.; Bisht, N.S.; Kumar, G. Synthesis of Zinc oxide nanoparticles using leaf extract of Viola canescens Wall. ex, Roxb. and their antimicrobial activity. J. Pharmacogn. Phytochem. 2017, 6, 1301-1304.

15. Khajuria, A.K.; Bisht, N.S.; Manhas, R.K.; Kumar, G. Callus mediated biosynthesis and antibacterial activities of zinc oxide nanoparticles from Viola canescens: An important Himalayan medicinal herb. SN Appl. Sci. 2019, 1, 455. [CrossRef]

16. Khajuria, A.K.; Negi, A.; Bisht, N.S.; Mayura, V.; Kandwal, A. Green synthesis, characterization and antimicrobial activity of synthesized zinc oxide nanoparticles using root extract of Viola canescens Wall. ex. Roxb. Asian J. Chem. 2019, 31, 551-554. [CrossRef]

17. Khan, M.A.; Ahmad, W.; Ahmad, M.; Nisar, M. Hepatoprotective effect of the solvent extracts of Viola canescens Wall. ex. Roxb. against $\mathrm{CCl} 4$ induced toxicity through antioxidant and membrane stabilizing activity. BMC Complement Altern. Med. 2017, 17, $1-11$.

18. Khajuria, A.K.; Bisht, N.S.; Krishan, R. Effect of 2, 4-D and cytokinins on callus induction in different explants of Viola canescens wall. Ex, Roxb. Plant Arch. 2017, 17, 833-838.

19. Khajuria, A.K.; Bisht, N.S. Indirect in vitro Regeneration of Viola canescens Wall. ex, Roxb. by using Leaf Calli. Plant. Tissue Cult. Biotech. 2018, 28, 215-222. [CrossRef]

20. Khajuria, A.K.; Chandra, S.; Manhas, R.K.; Bisht, N.S. Effect of different PGRs on in vitro organogenesis in Viola canescens Wall. ex. Roxb. from petiole callus culture. Vegetos 2019, 32, 353-362. [CrossRef]

21. Nadeem, M.; Palni, L.M.S.; Purohit, A.N.; Pandey, H.; Nandi, S.K. Propagation and conservation of Podophyllum hexandrum Royle: An important medicinal herb. Biol. Conserv. 2000, 92, 121-129. [CrossRef]

22. Sharma, S.; Katoch, V.; Rathour, R.; Sharma, T.R. In vitro propagation of endangered temperate Himalayan medicinal herb Picrorhiza kurroa Royle ex benth using leaf explants and nodal segments. J. Plant Biochem. Biotechnol. 2010, 19, 111-114. [CrossRef]

23. Jha, T.B.; Dafadar, A.; Chaudhuri, R.K. Somatic Embryogenesis in Swertia chirata Buch. Ham. ex Wall.-A Multipotent Medicinal Herb. Asian J. Biotechnol. 2011, 3, 186-198. [CrossRef]

24. Bisht, A.K.; Bhatt, A.; Dhar, U.; Bhatt, A.; Dhar, U. Note on somatic embryogenesis and synthetic seed production in Angelica glauca: A valuable medicinal plant of Himalaya. J. Med. Plants Res. 2015, 9, 419-425.

25. Kaushal, S.; Sidana, A. Somatic embryogenesis and plant regeneration from cell suspension cultures of Gentiana kurroo Royle. Ann. Plant Sci. 2018, 7, 2239-2246. [CrossRef]

26. Narayani, M.; Varsha, M.S.; Potunuru, U.R.; Beaula, W.S.; Rayala, S.K.; Dixit, M.; Chadha, A.; Srivastava, S. Production of bioactive cyclotides in somatic embryos of Viola odorata. Phytochemistry 2018, 156, 135-141. [CrossRef] [PubMed]

27. Ohga, Y.; Ono, M.; Furuno, K. Somatic embryogenesis and plant regeneration from hypocotyls and cotyledons of Angelica acutiloba and Foeniculum vulgare. Rep. Kyushu Branch Crop Sci. Soc. Jpn. 1989, 56, 89-91. 
28. Wakhlu, A.K.; Nagari, S.; Barna, K.S. Somatic embryogenesis and plant regeneration from callus cultures of Bunium persicum Boiss. Plant. Cell. Rep. 1990, 9, 137-138. [CrossRef] [PubMed]

29. Rizvi, M.Z.; Kukreja, A.K.; Bisht, N.S. In vitro propagation of an endangered medicinal herb Chlorophytum borivilianum Sant. et Fernand. through somatic embryogenesis. Physiol. Mol. Biol. Plants 2010, 16, 249-257. [CrossRef] [PubMed]

30. Singh, R.; Rai, M.K.; Kumari, N. Somatic embryogenesis and plant regeneration in Sapindus mukorossi Gaertn. from leaf-derived callus induced with 6-benzylaminopurine. Appl. Biochem. Biotechnol. 2015, 177, 498-510. [CrossRef] [PubMed]

31. Sagare, A.P.; Lee, Y.L.; Lin, T.C.; Chen, C.C.; Tsay, H.S. Cytokinin-induced somatic embryogenesis and plant regeneration in Corydalis yanhusuo (Fumariaceae)—A medicinal plant. Plant Sci. 2000, 160, 139-147. [CrossRef]

32. Chen, J.T.; Chang, W.C. Effects of auxins and cytokinins on direct somatic embryogenesison leaf explants of Oncidium 'Gower Ramsey'. Plant Growth Regul. 2001, 34, 229-232. [CrossRef]

33. Raghavan, V. Role of 2, 4-dichlorophenoxyacetic acid (2, 4-D) in somatic embryogenesis on cultured zygotic embryos of Arabidopsis: Cell expansion, cell cycling, and morphogenesis during continuous exposure of embryos to 2, 4-D. Am. J. Bot. 2004, 91, 1743-1756. [CrossRef] [PubMed]

34. Chaudhary, K.; Prakash, J. Effect of 2, 4-D and Picloram on Somatic Embryogenesis in Carica papaya var. P-7-9. Plant Tissue Cult. Biotechnol. 2019, 29, 25-32. [CrossRef]

35. Méndez-Hernández, H.A.; Ledezma-Rodríguez, M.; Avilez-Montalvo, R.N.; Juárez-Gómez, Y.L.; Skeete, A.; Avilez-Montalvo, J.; De-La-Peña, C.; Loyola-Vargas, V.M. Signaling overview of plant somatic embryogenesis. Front. Plant Sci. 2019, 10, 77. [CrossRef]

36. Gray, D.J.; Conger, B.V. Influence of dicamba and casein hydrolysate on somatic embryo number and culture quality in cell suspensions of Dactylis glomerata (Gramineae). Plant Cell Tissue Organ Cult. 1985, 4, 123-133. [CrossRef]

37. Varisai, M.S.; Wang, C.S.; Thiruvengadam, M.; Jayabalan, N. In vitro plant regeneration via somatic embryogenesis through cell suspension cultures of horsegram [Macrotyloma uniflorum (Lam.) Verdc.]. In Vitro Cell. Dev. Biol. Plant. 2004, 40, 284-289. [CrossRef]

38. Ageel, S.; Elmeer, P. Effects of casein hydrolysates and glutamine on callus and somatic embryogenesis of date palm (Phoenix dactylifera). N. Y. Sci. J. 2011, 4, 121-125.

39. Elmeer, K.E.S. Factors Regulating Somatic Embryogenesis in Plants. Somatic Embryogenesis and Gene Expression. In Somatic Embryogenesis and Gene Expression; Junaid, A., Srivastava, P.S., Sharma, M.P., Eds.; Narosa Publishing House: New Delhi, India, 2013; pp. 56-81.

40. Daniel, M.A.; David, R.H.A.; Caesar, S.A.; Ramakrishnan, M.; Duraipandiyan, V.; Ignacimuthu, S.; Al-Dhabi, N.A. Effect of l-glutamine and casein hydrolysate in the development of somatic embryos from cotyledonary leaf explants in okra (Abelmoschus esculentus L. monech). S. Afr. J. Bot. 2018, 114, 223-231. [CrossRef]

41. Fitch, M.M. High frequency somatic embryogenesis and plant regeneration from papaya hypocotyls callus. Plant Cell Tissue Organ Cult. 1993, 32, 205-212. [CrossRef]

42. Choi, Y.E.; Kim, J.W.; Yoon, E.S. High frequency of plant production via somatic embryogenesis from callus or cell suspension cultures in Eleutherococcus senticosus. Ann. Bot. 1999, 83, 309-314. [CrossRef]

43. Kim, Y.S.; Lim, S.; Choi, Y.E.; Anbazhagan, V.R. High frequency plant regeneration via somatic embryogenesis in Podophyllum peltatum L., an important medicinal plant for source of anticancer drug. Curr. Sci. 2007, 92, 662-666.

44. Zavattieri, M.A.; Frederico, A.M.; Lima, M.; Sabino, R.; Arnholdt-Schmitt, B. Induction of somatic embryogenesis as an example of stress-related plant reactions. Electron. J. Biotechnol. 2010, 13, 12-13. [CrossRef]

45. Roustan, J.P.; Latche, A.; Fallot, J. Control of carrot somatic embryogenesis by $\mathrm{AgNO}_{3}$, an inhibitor of ethylene action: Effect on arginine decarboxylase activity. Plant Sci. 1990, 67, 89-95. [CrossRef]

46. Al-Khayri, J.M.; Al-Bahrany, A.M. Silver nitrate and 2-isopentyladenine promote somatic embryogenesis in date palm (Phoenix dactylifera L.). Sci. Hortic. 2001, 89, 291-298. [CrossRef]

47. Rai, M.K.; Jaiswal, V.S.; Jaiswal, U. Shoot multiplication and plant regeneration of guava (Psidium guajava L.) from nodal explants of in vitro raised plantlets. J. Fruit. Ornam. Plant Res. 2009, 17, 29-38.

48. Rizvi, M.Z.; Kukreja, A.K.; Bisht, N.S. Plant regeneration in Chlorophytum borivilianum Sant. et Fernand. from embryogenic callus and cell suspension culture and assessment of genetic fidelity of plants derived through somatic embryogenesis. Physiol. Mol. Biol. Plants 2012, 18, 253-263. [CrossRef]

49. Corbin, C.; Decourtil, C.; Marosevic, D.; Bailly, M.; Lopez, T.; Renouard, S.; Doussot, J.; Dutilleul, C.; Auguin, D.; GiglioliGuivarc'H, N.; et al. Role of protein farnesylation events in the ABA-mediated regulation of the pinoresinol-lariciresinol Reductase 1 (LuPLR1) gene expression and lignan biosynthesis in flax (Linum usitatissimum L.). Plant Physiol. Biochem. 2013, 72, 96-111. [CrossRef]

50. Markulin, L.; Drouet, S.; Corbin, C.; Decourtil, C.; Garros, L.; Renouard, S.; Lopez, T.; Mongelard, G.; Gutierrez, L.; Auguin, D.; et al. The control exerted by ABA on lignan biosynthesis in flax (Linum usitatissimum L.) is modulated by a Ca2+ signal transduction involving the calmodulin-like LuCML15b. J. Plant Physiol. 2019, 236, 74-87. [CrossRef]

51. Markulin, L.; Corbin, C.; Renouard, S.; Drouet, S.; Durpoix, C.; Mathieu, C.; Lopez, T.; Auguin, D.; Hano, C.; Lainé, É. Characterization of LuWRKY36, a flax transcription factor promoting secoisolariciresinol biosynthesis in response to Fusarium oxysporum elicitors in Linum usitatissimum L. hairy roots. Planta 2019, 250, 347-366. [CrossRef]

52. Rojas-Lorz, L.; Arrieta-Espinoza, G.; Valdez-Melara, M.; Pereira, L.F.P.; Gatica-Arias, A. Influence of silver nitrate on somatic embryogenesis induction in Arabica Coffee (Coffea arabica L.). Braz. Arch. Biol. Technol. 2019, 62, e19180228. [CrossRef] 
53. Arnold Von, S.; Sabala, I.; Bozhkov, P.; Dyachok, J.; Filonova, L. Developmental pathways of somatic embryogenesis. Plant Cell Tissue Organ Cult. 2002, 69, 233-249. [CrossRef]

54. Kackar, A.; Bhat, S.R.; Chandel, K.P.; Malik, S.K. Plant regeneration via somatic embryogenesis in ginger. Plant Cell Tissue Organ Cult. 1993, 32, 289-292. [CrossRef]

55. Yusuf, N.A.; Annuar, M.S.; Khalid, N. Rapid micropropagation of Boesenbergia rotunda (L.) Mansf. Kulturpfl. (a valuable medicinal plant) from shoot bud explants. Afr. J. Biotechnol. 2011, 10, 1194-1199.

56. Verma, M.; Bansal, Y.K. Induction of somatic embryogenesis in endangered butterfly ginger Hedychium coronarium J. Koenig. Indian J. Exp. Biol. 2012, 50, 904-909.

57. Hazarika, B.N. Acclimatization of tissue-cultured plants. Curr. Sci. 2003, 85, 1704-1712.

58. Deb, C.R.; Imchen, T. An Efficient In vitro Hardening Technique of Tissue Culture Raised Plants. Biotechnology 2010, 9, 79-83. [CrossRef]

59. Chandra, S.; Bandopadhyay, R.; Kumar, V.; Chandra, R. Acclimatization of tissue cultured plantlets: From laboratory to land. Biotechnol. Lett. 2010, 32, 1199-1205. [CrossRef]

60. Perrino, E.V.; Silletti, G.N.; Erben, M.; Wagensommer, R.P. Viola cassinensislucana (Violaceae), a new subspecies from Lucanian Apennine, southern Italy. Phyton 2018, 58, 109-115. [CrossRef]

61. Slazak, B.; Sliwinska, E.; Saługa, M.; Ronikier, M.; Bujak, J.; Słomka, A.; Göransson, U.; Kuta, E. Micropropagation of Viola uliginosa (Violaceae) for endangered species conservation and for somaclonal variation-enhanced cyclotide biosynthesis. Plant Cell Tissue Organ Cult. 2015, 120, 179-190. [CrossRef]

62. Ballard, H.E.; Sytsma, K.J.; Kowal, R.R. Shrinking the violets: Phylogenetic relationships of infrageneric groups in Viola (Violaceae) based on internal transcribed spacer DNA sequences. Syst. Bot. 1999, 23, 439-458. [CrossRef] 